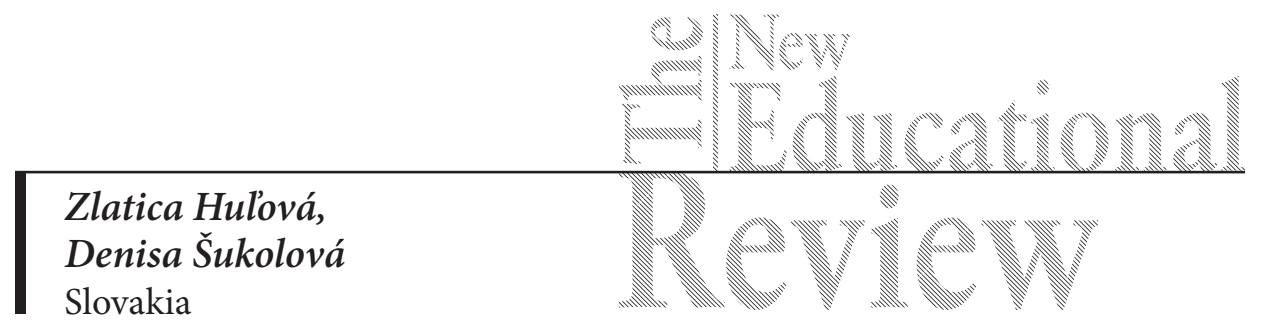

\title{
Slovak Primary Education Teachers' Views about and Attitudes towards Contents of Work and Technical Education
}

DOI: 10.15804/tner.2017.47.1.13

\begin{abstract}
The contribution is aimed at study of views and attitudes towards the contents of Technical education from the perspective of elementary school female teachers in Slovakia. Their measurement was carried out by a self-designed questionnaire which was a part of the research methods used (content analysis of curricular documents, international comparison, interview and observation). The originally designed questionnaire included items aimed at finding out views (evaluation of the importance of contents of education) and attitudes (cognitive, affective and conative components) of primary education teachers towards the contents of Technical education in the $4^{\text {th }}$ form of elementary school. The research sample consisted of 334 female teachers. According to results of analysis, teachers considered such themes as traditions and crafts or catering to be more important than themes connected with the use of technical materials and design and they also had more positive attitudes to such themes. Another conclusion is that explanations of the views on the importance of the preferred themes were accounted for mainly by the affective component of teachers' attitudes.
\end{abstract}

Keywords: female teachers, primary education, technical competence, views, attitudes, feminisation 


\section{Introduction}

Today, nobody doubts that the current state in Slovakia draws attention to shortcomings or challenges in the harmonization of the economic and educational policy (e.g. Workie Tiruneh at al., 2012; ÚPSVaR /Office of Labour, Social Matters and Family/,2015). It is frequently stated that education does not build continuously to the labour market needs and that the school system still accentuates quantitative and not qualitative parameters of education. However, one of the major paradoxes may be seen in the fact that despite significant progress in science and technology at the turn of the $21^{\text {st }}$ century, technical education is not paid sufficient attention to in Slovakia. This situation is long-term despite the opposite direction of European Union developed countries (Kozík \& Škodová, 2008; Urban, 2007). Undersizing and poor continuity of technical education at lower stages of education has a subsequent impact also on pupils' low interest in technical fields during higher vocational education, which is in sharp contradiction with the national needs and employers' needs (e.g., Vasiliak, 2007; ÚPSVaR, 2015).

\section{State of Development of Basic Competences in Science and Technology in Slovakia}

In 2005 the European Council and the European Parliament passed the document Key Competences for Lifelong Learning - A European Reference Framework, concluded with a recommendation to aim education at generating qualities in human resources that represent a global leader. Thus, curricula should contain mainly key competences for mathematical literacy and competences for the area of science and technology. As far as the technical competence is concerned, the document established requirements for knowledge including knowledge of principles of the workings of the world, technology, products and processes.

In general, we may speak also of achieving technical literacy (Kozík \& Depešová, 2007). Its formation and acquisition of work habits takes place at all stages of education and has a long tradition in Slovakia (Lukáčová \& Bánesz, 2007). In 2008 the Slovak government created legislative conditions for a system reform, by the introduction of a two-level model of curriculum emphasizing orientation of goals to the development of key competences (Kmet', 2011). Within modifications for primary education, a separate subject Technical Education remained only in the $4^{\text {th }}$ form, with one period per week. It contained five thematic units: "Creative Use of Technical Materials" "Basics of Design", "Care for the Environment", "Catering and Food Preparation"and "Folk Traditions and Crafts". The definition of goals was based on general requirements of scientific and technological literacy and general 
goals of primary education. Their framing included three basic levels of pupil personality holistic development: the level of knowledge - education about technology, level of values and attitudes - education for the relationship to technology, level of working activities, experience and skills - education through technology (National Educational Programme - ISCED1, 2008)

The contribution covers measurement in the context of the 2008 content standard currently implemented only in the $4^{\text {th }}$ form at elementary schools in Slovakia.

\section{Feminisation of Education as a Possible Cause of Hidden Curriculum Existence}

Technical education at elementary schools has been so far assessed from many aspects. There are comments on teachers' competences (Ďuriš, 2007), insufficient technological equipment at schools (Bánesz, Lukáčová \& Sitáš, 2010), historical connections, changes in the content of education or their justification (Kožuchová et al., 2011, Kozík, 2013). However, we have not come across any study of the issue from the perspective of considerable feminisation in our school system.

In the simplest conception, a branch is considered feminised where more than $2 / 3$ of the total number of employees are women (e.g., Tokárová, 2006; Bank, 2007). According to the report by EACEA P9 Eurydice (2010), foreign research points to the fact that until recently more than $60 \%$ of the people working in primary and secondary education in all EU countries except Greece and Luxembourg were women. The report also states that feminisation of the teaching profession in the majority of the EU countries exists mainly at the level of preprimary and primary education. Some explain this situation by the connection of the teaching profession with care, family life or emotional sensitivity of women (e.g., Fischman, 2000; Drudy, 2008). Weiner (2002) writes that women accept low salaries or a lower position within a hierarchy easier, because the nature of the teacher's work is compatible with their domestic duties.

However, in addition to the number of women it is necessary to look also at other facts related to this phenomenon. Skelton (2002) notes, in addition to the statistical aspect, also the cultural and political aspect of the phenomenon. From the perspective of the cultural aspect of feminisation, a question arises naturally how female teachers' preferences in the area of technical education reflect in the educational practice.

\section{Explicit definition of the objectives of study}

According to the survey studies, the knowledge in the area of education feminisation is divided into two main streams of questions characteristic of all 
themes unfolding from the issue. One aspect concerns the question why the area of education has become "gender unbalanced"; the other aspect tracks the line of impacts of this phenomenon on the process of education and outcomes of education (Kelleher et al., 2011). The present study deals with the other aspect, while the problem studied is considered to go beyond the national occurrence. From this point of view Slovakia is namely an example of a country still failing to address the situation described above. In 2014 the portion of men in primary education in the Slovak Republic was below 7\% (MŠVVaŠ SR / Ministry of Education, Science, Research and Sport of the Slovak Republic/,2014). At the same time, the lack of male role models for pupils was a cause for great concern, for which several European countries adopted national strategies with the aim to increase the number of male teachers in primary education.

On the basis of the above theoretical background, the following objectives of the study were formulated: (1) Find out teachers' views on the importance of individual thematic units of Technical Education and rank them in order of their preference; (2) find out teachers' attitudes (cognitive component, affective component, conative component) towards individual thematic units of Technical Education and rank them in order of their preference; and (3) find out which attitude components explain the views on the importance of individual thematic units of Technical Education.

\section{Methods}

The research sample consisted of 334 female teachers of primary education. The teachers' exact age was not established, but the middle value (median) determining the length of service ranged from 15 to 20 years in the whole sample. The sampling of the participants may be considered purposive with elements of stratification, since the sample included only teachers of the $4^{\text {th }}$ forms of elementary schools, with the participants representing all regions of Slovakia. Another element of stratification was applied at the level of the size of the town where the school was located. Approximately a half of the teachers was from smaller towns and municipalities $(n=193)$ and the other half from district and regional towns $(n=141)$. All the teachers participated in the research voluntarily, which they confirmed by their informed consent at the beginning of the questionnaire. Originally, also male teachers were included in the sample of participants, whom we finally decided to exclude from analyses due to their low number and subsequent limited possibility to make inter-gender comparisons. Also, a possible distortion of data was assumed. 
To measure views and attitudes, an original questionnaire was designed, consisting of three parts: (1) finding out socio-demographic characteristics; (2) finding out views on the importance of thematic units (defined above) within Technical Education; and (3) finding out attitudes towards thematic units within Technical Education. Attitudes were measured at the cognitive, affective and conative levels. To ensure a higher content validity of the measurement, individual components of attitudes were recorded at descriptions of specific activities falling under individual thematic units. Each thematic unit was represented in the questionnaire by the number of activities matching its periods by the National Educational Programme of 2008. When calculating comparable indices within individual thematic units, the attitude score had to be standardized. In the second and third part of the questionnaire, a 10-point scale was used, with 1 meaning the minimum and 10 meaning the maximum.

\section{Results}

Table 1 (Objective 1) shows a summary of descriptive characteristics of the variable "views on the importance of thematic units of Technical Education". On the basis of mean values of the variables for the whole sample of participants, it can be stated that the teachers ranked the thematic units from the most important to the least important as follows: Traditions and Crafts $(\mathrm{M}=8.44)$, Catering and Food Preparation $(M=8.19)$, Creative Use of Technical Materials $(M=7.83)$, Basics of Design $(M=7.06)$. To compare individual parameters, paired t-tests and the Wilcoxon rank tests were used (the variable "view on the importance of the thematic unit Traditions and Crafts" did not fulfil the condition for normal distribution of data). Results of statistical analyses are shown in Table 2. In summary,

Table 1. Descriptive characteristics of variables expressing views on the importance of thematic units

\begin{tabular}{|c|c|c|c|c|c|}
\hline & $\mathrm{N}=334$ & TECH & KON & STRAV & TRAD \\
\hline $\mathbf{M}$ & & 7.83 & 7.06 & 8.19 & 8.44 \\
\hline $\mathrm{MDN}$ & & 8.00 & 7.00 & 9.00 & 9.00 \\
\hline SD & Teachers & 1.94 & 2.07 & 1.82 & 1.78 \\
\hline Skewness & & -.67 & -.35 & -.87 & -1.35 \\
\hline Kurtosis & & -.37 & -.50 & -.08 & 1.67 \\
\hline
\end{tabular}


it can be stated that the statistical significance was not fully confirmed only in the case of comparison of the variable "the importance of the thematic unit Catering and Food Preparation and the thematic unit Creative Use of Technical Materials". TECH - Creative Use of Technical Materials, KON - Basics of Design, STRAV - Catering and Food Preparation, TRAD - Folk Traditions and Crafts

Table 2. Results of comparison analyses for the variables expressing views on the importance of thematic units

\begin{tabular}{|c|c|c|c|c|c|c|}
\hline $\mathrm{N}=334$ & \multicolumn{2}{|c|}{ M } & \multicolumn{2}{|c|}{$\mathrm{MDN}$} & $t / Z$ & $\mathrm{P}$ \\
\hline TRAD_STRAV & 8.44 & 8.19 & 9.00 & 9.00 & 3.651 & .000 \\
\hline TRAD_TECH & 8.44 & 7.83 & 9.00 & 8.00 & 4.761 & .000 \\
\hline STRAV_TECH & 8.19 & 7.83 & 9.00 & 8.00 & 1.908 & .057 \\
\hline STRAV_KON & 8.19 & 7.06 & 9.00 & 7.00 & 7.565 & .000 \\
\hline TECH_KON & 7.83 & 7.06 & 8.00 & 7.00 & 9.168 & .000 \\
\hline
\end{tabular}

$\mathrm{t}$ - paired $\mathrm{t}$-test result, $\mathrm{Z}$ - Wilcoxon rank test result, $\mathrm{p}$ - significance

Table 3 (Objective 2) shows a summary of descriptive characteristics of the variables characterizing the teachers' attitudes towards individual thematic units of Technical Education. On the basis of the mean values of the summative score (sum of the cognitive, affective and conative components) of individual attitudes for the whole sample of female participants it can be stated that the female teachers have the most positive attitudes towards the theme "Catering and Food Preparation" ( $M-25.60)$, then towards "Folk Traditions and Crafts" ( $\mathrm{AM}=23.17)$, followed by "Creative Use of Technical Materials" (AM = 19.89) and finally "Basics of Design" $(\mathrm{AM}=17.09)$. To compare individual parameters, paired t-tests and the Wilcoxon rank test were carried out (the variable "summative score" for the attitude towards the thematic unit Catering and Food Preparation did not fulfil the condition for normal distribution of data). Results of statistical analyses are presented in Table 4. In summary, it can be stated that the statistical significance was confirmed for all the variables compared. 
Table 3. Descriptive characteristics of variables characterising attitudes towards contents/thematic units

\begin{tabular}{|c|c|c|c|c|c|c|}
\hline M & MDN & SD & Skew & Kurt & $\mathrm{N}=334$ & Thematic unit/Attitudes \\
\hline & & & & & & TECH \\
\hline 7.05 & 7.00 & 1.53 & -.23 & -.49 & \multirow{19}{*}{ Teachers } & Knowledge (Cognitive component) \\
\hline 7.12 & 7.33 & 1.65 & -.38 & -.33 & & Relationship (Affective component) \\
\hline 6.52 & 6.33 & 1.73 & .20 & -.61 & & $\begin{array}{l}\text { Performance frequency (Conative } \\
\text { component) }\end{array}$ \\
\hline \multirow[t]{2}{*}{19.89} & 20.00 & 4.82 & -.21 & -.38 & & Summative score (All components) \\
\hline & & & & & & KON \\
\hline 5.87 & 5.83 & 1.95 & .77 & 6.48 & & Knowledge (Cognitive component) \\
\hline 6.18 & 6.25 & 1.53 & -.01 & -.10 & & Relationship (Affective component) \\
\hline 5.05 & 5.00 & 1.81 & .18 & -.06 & & $\begin{array}{l}\text { Performance frequency (Conative } \\
\text { component) }\end{array}$ \\
\hline \multirow[t]{2}{*}{17.09} & 16.83 & 4.53 & .14 & -.06 & & Summative score (All components) \\
\hline & & & & & & STRAV \\
\hline 8.48 & 9.00 & 1.82 & -1.53 & 2.67 & & Knowledge (Cognitive component) \\
\hline 8.59 & 9.00 & 1.79 & -1.39 & 1.30 & & Relationship (Affective component) \\
\hline 8.54 & 9.00 & 1.85 & -1.61 & 2.98 & & $\begin{array}{l}\text { Performance frequency (Conative } \\
\text { component) }\end{array}$ \\
\hline \multirow[t]{2}{*}{25.60} & 27.00 & 4.68 & -1.37 & 1.54 & & Summative score (All components) \\
\hline & & & & & & TRAD \\
\hline 7.94 & 8.50 & 1.94 & -.89 & .31 & & Knowledge (Cognitive component) \\
\hline 7.91 & 8.50 & 1.91 & -.56 & -.78 & & Relationship (Affective component) \\
\hline 7.24 & 7.50 & 2.30 & -.64 & .17 & & $\begin{array}{l}\text { Performance frequency (Conative } \\
\text { component) }\end{array}$ \\
\hline 23.17 & 24.00 & 5.41 & -.39 & .08 & & Summative score (All components) \\
\hline
\end{tabular}

Table 4. Results of comparison analyses for variables expressing the total attitude score towards individual contents/thematic units

\begin{tabular}{llllllc}
\hline \multicolumn{1}{c}{ N = 334 } & \multicolumn{2}{c}{ M } & \multicolumn{2}{c}{ MDN } & t/Z & p \\
\hline STRAV_TRAD & 25.60 & 23.17 & 27.00 & 24.00 & 8.381 & .000 \\
\hline TRAD_TECH & 23.17 & 19.87 & 24.00 & 20.00 & 10.150 & .000 \\
\hline TECH_KON & 19.87 & 17.09 & 20.00 & 16.83 & 10.141 & .000 \\
\hline
\end{tabular}


Table 5. Summary of regression models

\begin{tabular}{ccccc}
\hline Predictor/Attitude & R-Beta & R Square & F/Sig. & t/Sig. \\
\hline Cognitive component & .375 & .141 & $54.001 / .000$ & $7.349 / .000$ \\
\hline Dependent variable: importance of the theme TECH \\
\hline Cognitive component & .359 & .129 & $49.020 / .000$ & $7.001 / .000$ \\
\hline Dependent variable: importance of the theme KON \\
\hline Affective component & .247 & .061 & $21.544 / .000$ & $4.642 / .000$ \\
\hline Dependent variable: importance of the theme STRAV \\
\hline Affective component & .409 & .167 & $66.436 / .000$ & $8.151 / 0.000$ \\
\hline \multicolumn{4}{c}{ Dependent variable: importance of the theme TRAD } \\
\hline
\end{tabular}

Predictor - explaining variable; R-Beta - correlation coefficient between the predictor and the variable explained (view on the importance), in this case representing also the standardized coefficient Beta in the table of regression coefficients; R Square - coefficient of determination; F/Sig. - result of the model significance test; $t$ /Sig. - result of the test assuming significance of the predictor in the model

Table 5 (Objective 3 ) presents a summary of the parameters of linear regression models showing the statistical dependence of views on the importance of thematic units on attitudes towards the thematic units ${ }^{1}$. In the first step, correlation matrices were made between the dependent variables (views on the importance) and the predictors (components of attitudes). In the second step, multiple linear regression analysis was carried out by means of the stepwise method. Next, a regression model was chosen, with its predictive values as high as possible with a meaningful number of predictors that were compared in the overall degree of their influence on the dependent variable. On the basis of the given results, it may be observed that within all the themes studied, a regression model that contained only one predictor appeared to be the most meaningful (supplemented additional variable did not considerably increase the quality of the regression model published). Even despite the statistical significance of the models and regressors the percentage of variability of the dependent variables explained by individual models is relatively low. However, the lower predictive value of the models could be expected due to the character and number of the variables added to the model (they were only components of attitudes - views are accounted for also by other explaining vari-

1 Attitudes were perceived as predictors due to their greater stability in time and higher consistency when compared with views. Thus, it is hypothetically assumed that attitudes towards the issue influence views rather than vice versa, although, of course, the possibility of a reversed course of influence is not excluded. 
ables). However, it is obvious from the above results that the affective component of attitude plays a greater role in preferred themes (Traditions and Crafts, Catering and Food Preparation), while the cognitive component of attitude plays a greater role in less favourable themes (Creative Use of Technical Materials, Basics of Design).

\section{Discussion}

The female teachers consider thematic units such as Traditions and Crafts or Catering and Food Preparation as more important than themes connected with the use of technical materials or basics of design. They report also more positive attitudes within the former themes. The finding is not surprising since Slovakia is considered to be oriented conservatively, which includes still a relatively high degree of gender stereotyping and gender inequality (e.g., MPSVaR SR, 2016). This is, according to Bosá (2003), connected with a clear image of "masculinity" and "femininity" drawn against the background of the traditional role division where the woman is a sensitive mother. However, the fact that two more significant thematic units in the context of the development of competences in science and technology were not preferred either in the case of importance evaluation or in the case of attitudes studied indicates a possibility of a hidden curriculum in this area, operating not fully in line with general requirements for the increase in the quality of competences in the area of science and technology. Our findings are thus consistent with many studies indicating direct impacts of the sector feminisation on the educational process (e.g., UNESCO - IIEP, 2011).

The study results also point to the fact that the strategy of policies should also address the enormous prevalence of female teachers at elementary schools (MŠVVaŠ SR, 2014), not only content innovations. In addition to measures aimed at cumulating numbers of male teachers in pre-primary and primary education there is, of course, a possibility to focus on undergraduate training of future female teachers or their continuing education. We believe that the results in the second part of our study supplemented also by findings from the research methods used could be of use also in this respect. We found out that as far as views on the importance of preferred themes were concerned (Traditions and Crafts, Catering and Food Preparation), their explanation rested on the affective rather than cognitive or conative components of attitude. In contrast, as far as views on the importance of less attractive themes were concerned (Creative Use of Technical Materials, Basics of Design), their explanation rested mainly on the cognitive component 
of attitude during preparation for Technical Education. However, we believe that the key is the recommendation aimed unambiguously at strengthening training interventions up to the level of experiencing and emotions that seem to be of the key importance in the formation of views and attitudes towards this issue.

One of the trends in the study of this issue should be an empirical design taking into account measurement of impacts of school feminisation on education outcomes and on performance of various groups of students (boys vs. girls, pupils from families with a lower SES, etc.) (Zuze \& Redy, 2011 in: UNESCO - IIEP, 2011). This type of research could in future give an insight into gender differences in such a specific area as science and technology.

\section{References}

Bank, B.J. (Ed.) (2007). Gender and Education: An Encyclopaedia. Westport London: Praeger.

Bánesz, G., Lukáčová, D., \& Sitáš, J. (2010). Technické vzdelávanie v digitálnom prostredí. Nitra: UKF.

Bosá, M. (2003) Čo všetko sú rodové stereotypy. In: UPGRADE PRE SEXUÁLNU VÝCHOVU, Zborník z konferencie, Bratislava: Veda - KVSBK SAV, 2003, 53-61.

Drudy, S. (2008). Professionalism, performativity and care: Whither teacher education for a gendered profession in Europe. In B. Hudson \& P. Zgaga, eds. Teacher education policy in Europe: A voice of higher education institutions. Umeå: Faculty of Teacher Education, University of Umeå, pp. 43-62.

Ďuriš, M. (2007). Odborná a pedagogická spôsobilost’ učitela technickej výchovy, ako klúčová kompetencia. In: Klúčové kompetencie a technické vzdelávanie - medzinárodná vedecko-odborná videokonferencia, Prešov. [CD ROM]. Available on:

http://www.pulib.sk/elpub2/FHPV/Pavelka2/pdf_doc/duris.pdf

Fischman, G. (2000). Imagining teachers: Rethinking gender dynamics in teacher education. New York: Rowman \& Littlefield.

Gender Differences in Educational Outcomes: Study on the Measures Taken and the Current Situation in Europe (2010). Brussels: EACEA P9 Eurydice. Available on:

http://eacea.ec.europa.eu/education/Eurydice/documents/thematic_reports/120SK.pdf

Gender Equality in Education: Looking beyond Parity An IIEP Evidence-Based Policy Forum (2011). Paris: UNESCO IIEP. Available on:

https://genderpolicyforum.files.wordpress.com/2012/02/gender_policy_forum_outcome_report21.pdf

Kelleher, F. et. al (2011). Woman and the teaching profession. Exploring the feminisation debate. London: Commonwealth Secretariat.

Key competences for lifelong learning - Recommendation of the European Parliament and of the Council. (2015). Brussels: EC. Available on: http://eur-lex.europa.eu/legal-content/ EN/TXT/PDF/?uri=CELEX:52005PC0548\&from $=$ SK 
Kmet', P. (2011). Štátny a školský vzdelávací program: Základné dokumenty kurikulárnej transformácie vzdelávania na Slovensku. In: Medzinárodná vedecká elektronická konferencia pre doktorandov, vedeckých pracovníkov a mladých vysokoškolských učitelov, Prešov: FHPV PU, 2011, 506-514.

Kozík, T., \& Depešová, J. (2007). Technická výchova v Slovenskej republike v kontexte vzdelávania v krajinách Európskej únie. Nitra: PF UKF v Nitre.

Kozík, T., \& Škodová, M. (2008). Školská reforma z pohladu technického vzdelávania. Technológia vzdelávania, 16 (8), 4-8.

Kožuchová, M. a i. 2011. Elektronická učebnica didaktika technickej výchovy. [online]. [cit.: 2016-04-10], Bratislava. Available on: http://utv.ki.ku.sk.

Lucas, R. E. (1988). On the Mechanics of Economic Development. Journal of Monetary Economics, 22.

Lukáčová, D., \& Bánesz, G. (2007). Premeny technického vzdelávania. Nitra: PF UKF.

Prognóza očakávaných budúcich potrieb zamestnancov do roku 2020 v SR bez BSK. (2015). ÚPSVaR. Available on: http://www.upsvar.sk/buxus/docs/statistic/NP_prognozy/Nove/ Prog-noza_ocakavanych_buducich_potrieb_zamestnancov_do_roku_2020_v_SR_bez_ BSK.pdf

Skelton, Ch. (2002). The feminisation of schooling or re-masculinising primary education? International Studies in Sociology of Education, 12 (1), 77-96.

Súhrnná správa o stave rodovej rovnosti na Slovensku za rok 2015 (2015). MPSVaR SR. Available on: http://hsr.rokovania.sk/data/att/152094_subor.pdf

Štátny vzdelávací program pre 1. Stupeň základnej školy v SR - ISCED 1 - primárne vzdelávanie (2008). MŠVVaŠ. Available on: http://www.statpedu.sk/sites/default/files/

dokumenty/statny-vzdelavaci-program/isced1_spu_uprava.pdf

Tokárová, A. (2006). Feminizácia v školstve na Slovensku a jej sociálno-pedagogické súvislosti. In: GENDER-RODOVOSŤ v pedagogickom výskume a praxi. Trnava: UCM, pp. 30-42.

Urban, I. (2007). Technická a technologická kompetentnot občanov EÚ ako klúčový determinant úspešnosti sútaží EÚ s d’alšími globálnymi aktérmi. In: Klúčové kompetencie a technické vzdelávanie. Prešov. [CD ROM]. Available on: http://www.pulib.sk/elpub2/ FHPV/Pavelka2/pdf_doc/urban.pdf

Vasiliak, J. (2007). Vplyv technickej výchovy na žiakov základných škôl a na ich d’alšie odborné vzdelávanie. In: Klúčové kompetencie a technické vzdelávanie. Prešov. [CD ROM]. Available on: http://www.pulib.sk/elpub2/FHPV/Pavelka2/pdf_doc/vasiliak.pdf

Weiner, G. (2002). Uniquely similar or similarly unique? Education and development of teachers in Europe. Teaching Education, 13(2), 273-288.

Workie Tiruneh, M., Štefánik, M., Lichner, I., Horvát, P., \& Bujňáková, T. (2012). Predvídanie potrieb trhu práce v SR: teoretické východiská a empirické výsledky. Bratislava: EKONÓM.

Zist'ovanie kvalifikovanosti pedagogických zamestnancov a odbornosti vyučovania podla stavu k 31. 01. 2014 (2014). MŠVVaŠ SR. Available on: https://www.minedu.sk/data/ files/4172.pdf 